JUPIIS: Jurnal Pendidikan Ilmu-ilmu Sosial, 11 (2) (2019): 260-272

DOI: https://doi.org/10.24114/iupiis.v11i2.13841

JUPIIS: Jurnal Pendidikan Ilmu-ilmu Sosial

Available online http://jurnal.unimed.ac.id/2012/index.php/jupiis

\title{
Etnografi Masyarakat dan Hukum Adat Kabupaten Humbang Hasundutan Sumatera Utara
}

\section{Ethnographic Society and Customary Law Humbang Hasundutan Regency, North Sumatra}

\author{
Yudhi Ramadani Harahap1)*, Ibnu Hajar Damanik2) \& Robert Sibarani3) \\ 1) Program Pasca Sarjana Antropologi Sosial Universitas Negeri, Indonesia \\ 2) Fakultas Ilmu Pendidikan, Universitas Negeri Medan, Indonesia \\ 3) Fakultas Ilmu Budaya, Universitas Sumatera Utara, Indonesia
}

Diterima: 29 Maret 2019; Disetujui: 20 Juli 2019; Dipublish: 01 Desember 2019

\begin{abstract}
Abstrak
Naskah ini merupakan "blue print" masyarakat dan hukum adat di Kabupaten Humbang Hasundutan Sumatera Utara. Bertujuan menemukan solusi penyelesaian sengketa-konflik terkait sumber daya agraria. Hak akses pada tanah ulayat, implementasi terapan dalam penentuan kebijakan, eksplorasi, mitigasi konflik. Mendeskripsikan sistem hukum dan kearifan lokal yang hidup di masyarakat adat. Metode penelitian riset menggunakan penelitian kualitatif dengan pendekatan Etnografi James P. Spradley. Teknik pengumpulan data dengan wawancara mendalam, observasi partisipasi dan tradisi lisan. Etnografi ini bersifat holistik-integratif, thick description, dan analisis kualitatif untuk mendapatkan native's point of view. Hasil penelitian mengungkapkan mekanisme pewarisan secara genologis kepada anak dan kerabat terdekat. Pewarisan yang diakui resesi adat, tanah panjaean untuk anak laki-laki atau ulos na sora buruk untuk anak perempuan boru. Mekanisme Jual Beli ulos tu piso, Gadai dondon, Pemberian, Kontrak. Bentuk entitas sosial, bius, partolian, golat, huta, marga raja yang merupakan struktur adat yang berperan pemegang hak akses ulayat. Pengambil Keputusan dan penyelesaian sengketa, Pagopago, Horja, Bius, Raja Nihuta, Bius Raja, Paradaton, Paripe, Perantau enkulturasi. Aspek sosial-politik komunitas Sionom Hudon, PBM, Sihas, Ketua lembaga, Raja Nihuta, Bius Raja, Paradaton, Paripe.
\end{abstract}

Kata Kunci: Masyarakat dan Hukum Adat, Kearifan Lokal, Sistem Tenurial, Sumber Daya Agraria.

\begin{abstract}
This scrip is a "blue print" of the community and customary law in Humbang Hasundutan District of North Sumatra. Aim to find solutions to resolve conflicts related to agrarian resources. Access rights to communal land, applied implementation in policy determination, exploration, conflict mitigation. Describe the legal system and local wisdom that live in indigenous peoples. The research research method uses qualitative research with the ethnographic approach of James P. Spradley. The technique of collecting data is in-depth interviews, participant observation and oral traditions. This ethnography is holistic-integrative, thick description, and qualitative analysis to get native's point of view. The results of the study revealed the mechanism of genological inheritance to children and closest relatives. Inheritance recognized as customary recession, panjaean land for boys or ulos na so buruk for boru girls. Mechanism of buying and selling ulos tu piso, dondon mortgage, giving, contract. Forms of social entities, bius, partolian, golat, huta, marga raja which are customary structures that play the role of holders of communal access rights. Decisionmakers and dispute resolution, Pago-pago, Horja, Bius, Raja Nihuta, Bius Raja, Paradaton, Paripe, Nomads enculturation. The socio-political aspects of the community of Sionom Hudon, PBM, Sihas, Chair of the institution, Raja Nihuta, Bius Raja, Paradaton, Paripe.
\end{abstract}

Keywords: Society and Customary Law, Local Wisdom, Tenure System, Agrarian Resources.

How to Cite: Harahap, Y.R., Damanik, I.H., \& Sibarani, R 2019 Etnografi Masyarakat dan Hukum Adat Kabupaten Humbang Hasundutan. JUPIIS: Jurnal Pendidikan IImu-ilmu Sosial, 11(2): 260-272.

${ }^{*}$ Corresponding author:

E-mail: yudhi.rhrp@gmail.com
ISSN 2085-482X (Print) ISSN $\underline{2407-7429}$ (Online) 


\section{PENDAHULUAN}

Dinamika pembangunan nasional, disatu sisi memberikan kontribusi peningkatan kualitas kesejahteraan hidup masyarakat, tetapi sisi lain juga berdampak pada merosotnya kualitas lingkungan hidup dan konflik horizontal. Seperti sengketa terkait penguasaan sumberdaya agraria atau sumberdaya alam yang telah terjadi sejak puluhan tahun lalu. Hampir di seluruh pelosok wilayah Indonesia. Sepanjang 2014 tercatat sedikitnya telah terjadi 472 konflik agraria di seluruh Indonesia dengan luasan area mencapai 2.860.977.07 hektar. Konflik ini melibatkan sedikitnya 105.887 kepala keluarga (KK).

Sengketa menyangkut persoalan tenurial adat yang mengkerucut terciptanya kondisi yang tidak harmoni. Ketimpangan penguasaan hak atas sumberdaya agraria, berdampak kerawanan sosial berbagai kelompok masyarakat, hingga turunnya tingkat kesejahteraan yang terlibat sengketa. Sengketa ini dimaknai sebagai "hubungan antara dua pihak atau lebih (individu atau kelompok) yang memiliki rasa sasaransasaran yang tidak sejalan" (Chris Mitchel dalam Fisher, 2000).

Fakta lapangan yang menyebutkan bahwa adanya tumpang-tindih tata batas desa, kawasan hutan Negara, yang terjadi pada sekitar 33.000-an desa di negeri ini, atau sekitar 25\% dari keseluruhan jumlah desa di Indonesia. Dalam sisi lain hanya sekitar 10\% saja kawasan hutan Negara yang selesai proses pengukuhan tata batasnya. Sengketa-sengketa seperti ini akan terus bertambah, seiring munculnya fenomena krisis pangan dan energi. Hingga memicu fenomena yang disebut land grabbing (perampasan lahan). Hal ini terjadi di wilayah adat yang berada di Humbang Hasundutan. Perampasan lahan dan penutupan akses oleh perusahaan PT. Pulp Lestari pada lahan masyarakat adat di daerah humbang hasundutan.

Terjadinya konflik di wilayah adat diantara beberapa pihak yang saling klaim pada suatu akses agraria. Sehingga perlu diperjelas sumber faktual kepemilikan suatu sumber daya. Beberapa fakta mengungkapkan bahwa sumber daya yang ada di Negeri ini dimiliki oleh masyarakat itu sendiri, yang terdiri dari beberapa kelompok masyarakat yang saling berserikat. Tetapi secara hukum positif aset yang merupakan kepemilikan komunal dialih fungsikan, dikarenakan beberapa faktor yang hingga akhirnya akses terhadap aset tidak dimiliki lagi oleh kelompok. Bukan hanya itu kepemilikan suatu sumber daya agraria juga secara fakta tidak memiliki bukti-bukti secara legal hukum pemerintah Indonesia. 
Sehingga hal ini merujuk pada konfik berkepanjangan antara pihak pemerintah, masyarakat, pengembang ataupun investor yang menggunakan sumber daya tertentu. Secara harafiahnya di Negeri ini, sumber daya dimiliki oleh masyarakat secara komunal adalah sumber daya penghidupan bagi kelompok yang tergabung dalam satu lingkaran adat. Adat bekerja dalam melestarikan dan melindungi segenap kelompok yang tujuan, satu rasa dan empati. Tetapi hukum dan adat tidak dapat bersenergi dengan hukum positif. Sehingga konflik yang terjadi di daerah selalu menimbulkan berbagai polemik hingga jatuhnya korban jiwa dan kerugian yang sangat besar bagi pihak yang terlibat dalam konflik. Tidak adanya kepastian hukum dan UU yang disepakati bersama untuk meneggakkan aturan yang berlaku, menjadikan pihak bertikai dalam kurun waktu yang cukup lama.

Oleh karena pentingnya dilakukan riset mendalam untuk mendapatkan kejelasan tentang sengketa agraria. Mengetahui bentuk masyarakat adat dan hukum yang berlaku, menetapkan subyek dan obyek hak atas kepemilikan sumber daya agraria. Oleh karena itu kajian etnografi masyarakat adat Humbang Hasundutan diperbuat, untuk dipergunakan sebagai titik acuan menentukan kebijakan yang berkolaborasi antara pemerintah, masyarakat Adat dan investor. Sehingga dapat meredam konflik di masyarakat. Mendongkrak peningkatan ekonomi dan pembangunan merata yang saling bersinergi di lingakaran pemerintah dan masyarakat adat.

\section{METODE PENELITIAN}

Metode penelitian riset ini menggunakan penelitian kualitatif dengan pendekatan Etnografi James P. Spradley. Teknik pengumpulan data menggunakan teknik wawancara secara mendalam, observasi partisipasi dan tradisi lisan. Etnografi ini bersifat holistik-integratif, thick description, dan analisis kualitatif untuk mendapatkan native's point of view.

Metode ini didasarkan atas 5 prinsip, yaitu teknik tunggal, identifikasi tugas, maju bertahap, penelitian orisinal dan problem-solving. (Spradley, 1997). Langkah-langkah penelitian maju bertahap ini terdiri dari 12 langkah dimulai dengan suatu fokus yang luas pada langkah 1 sampai langkah ke 5 dan pada langkah ini merupakan bagian dari analisis awal atau permukaan penelitian yang dikerjakan. Dimulai dengan mengumpulkan data live in selama 2 bulan di Humbang Hasundutan. Turut serta dalam setiap kegiatan manigi di hutan yang dilakukan di masyarakat untuk memenuhi data. 
Mengumpulkan data dengan wawancara mendalam, tidak terstruktur akan tetapi sesuai dengan interview guide yang sudah disusun terlebih dahaulu. Kemudian mulai menyempit pada langkah ke 7 untuk penyelidikan intensif atas beberapa domain terpilih, lantas pada langkah ke 7 sampai 10 inilah kita menggunakan analisis yang mendalam (sistemis holistik). Megumpulkan data lapangan dan mulai memisahkan data sehingga mulai tampak jelas hasil yang dibutuhkan untuk mengkerucutkan fokus penelitian. Langkah ke 11 dan 12 meluas kembali menjadi generalisasi selanjutnya dipahami pula untuk mendapatkan native's point of view. Studi pustaka digunakan dalam pengumpulan data-data melalui sumber buku-buku, jurnal, tesis, desertasi dan media internet yang berkaitan dengan penelitian masyarakat adat, kearifan lokal, tradisi, nilai dan norma, simbolik, analisis budaya. Dokumen-dokumen arsip lama, catatan misionaris, memoir administrator Kolonial (Kolonila Nasional). Digunakan sebagai memperkuat hasil temuan dilapangan. Studi pustaka juga sebagai pembanding dan validasi data. Sehingga data didapatkan akurat dan dapat dipertahankan sesuai pakem penelitian.

\section{HASIL DAN PEMBAHASAN}

Humbang adalah dataran tinggi yang luas dan mirip dengan padang rumput kering yang di sana-sini hanya ditumbuhi belukar, bebatuan berkersik terkerat-kerat di banyak tempat saluran air yang sangat dalam dan di sepanjang dataran tersebut dibuka ladang padi basah, hauma saba (Vergouwen) gambaran seorang sarjana Belanda seabad silam mengenai Humbang ketika ia melakukan penelitian hukum adat masyarakat Batak. Saat ini, Humbang yang digambarkan oleh Vergouwen telah menjadi bagian dari sebuah kabupaten yang disebut sebagai Kabupaten Humbang Hasundutan. Dahulunya wilayah Humbang Hasundutan itu merupakan bagian dari wilayah administratif Kabupaten Tapanuli Utara yang mengalami pemekaran pada tahun 2003. Humbang Hasundutan memiliki luas sebesar 2.3335,33 km2 dengan ibukota di Dolok Sanggul. Berada di ketinggian 330-2.075 mdpl dengan relif tanah berbukit-bukit. Lahan perbukitan dan tropis, memungkinkan penduduknya untuk menanam kopi. Selain bermata pencaharian sebagai petani kopi, penduduk Humbang menyandarkan hidup dari hasil tumbak haminjon (hutan kemenyan) dan bertani holtikultura.

Bentuk-bentuk kearifan yang berlaku pada masyarakat Adat, Berkaitan dengan properti dan pewarisan (sistem tenurial 
tanah adat) diantaranya yaitu. Diparaja Merupakan sitem tradisional yang masih ada di masyarakat adat di Humbang Hasundutan. Merupakan suatu sitem peradilan yang sangat dihormati hasil keputusannya. Dimulai dari permasalahan rumah tangga, asusila, hingga sengeketa agraria. Peradilan dengan metode diparaja menjadi solusi dalam penyelesaian berbagai macam persengketaan. Tetapi bukan berarti tidak tergerus dengan perubahan. Apabila terjadi sengketa baik itu sengketa tanah maka untuk melerai konflik tersebut digunkan mekanisme diparaja. Kerabat yang bersengketa bertemu di dalam sebuah forum. Raja nihuta adalah pemanggku peradilan tersebut. raja nihuta bersifat sebagai penengah, penimbang, ataupun hakim untuk menyelesaikan permasalahan. Raja nihuta dianggap sebagai sosok yang bijaksana dan dapat menjalin keselarasan di setiap keputusan.

Secara teritorial merupakan ruang lingkup tempat tumbuh kembangnya dan enkultrasi langsung pada huta tersebut. Sistem aturan di dalam huta, dijalankan oleh raja nihuta. Raja nihuta merupakan pemangku kuasa didalam menyusun segala tindak tanduk peraturan yang menjadi tatanan dalam hidup di huta. Huta merupakan suatu daerah yang terkecil dari sistem adat yang ada dimasyarakat batak.
Masyarakat huta yang dipimpin oleh raja tadi menghidupkan peraturaan-peratuaan adat yang kuat. Struktur huta di terdiri dari beberapa pemangku: 1) Raja Nihuta, pemangku kuasa dihuta yang merupakan galur keturunan marga pemilik tanah; 2) Anggi Ni Raja, klan marga yang sama dan memiliki hubungan kerabat yang kuat dengan pemilik tanah dongan tubuh, berperan menggantikan raja di adat jika raja nihuta tidak ada; 3) Namora, merupakan kelompok hula hula yang memberikan nasehat dan berdiskusi untuk menuaikan keputusan raja nihuta; 4) Tuatua Ni Huta, merupakan kelompok orang yang memahami adat, kecendiakaan, pengetahuan sejarah, religius, yang memberikan nasehat dan gambaran adat untuk dipertimbangkan oleh Raja nihuta; 5) Paripe, merupakan penduduk huta yang terdiri dari marga raja, marga boru dan pendatang dihuta.

Dari catatan lapangan terlukiskan peran raja nihuta, bagaimana keputusannya terhadapat pelanggaran dan aset yang ada dihuta. Dizaman sekarang ini diparaja sedikit mendapat keraguan dimasyarakat adat. Banyak polemik yang terjadi bahwa raja nihuta tidak seorang yang bijaksana. Kekurangan pola fikir dan kepribadian dari seorang raja menjadi sarat utama. 
Fakta di lapangan menunjukkan bahwa Raja nihuta tidak memiliki kepribadian yang baik dan tidak dapat menjadi panutan bagi paripenya (penduduk desa). Pandangan kepada raja yang berdasarkan dari garis keturunan mendapat keraguan dari paripenya. Sebap pandangan paripe bahwa tidak mungkin dalam generasi itu semuanya memilki kepribadian yang baik, terkadang generasi berikutnya bisa keluar dari faidah kebijaksanaan seorang raja. Faktor itu sistem diparaja sekarang mendapat sikap skeptis dan mulai ditinggal di beberapa daerah adat.

Bius horja juga merupakan salah satu menkanisme mengatasi permasalahan dalam struktur masyarakat adat. Bius terdiri dari kesatuan raja raja nihuta, yang berfungsi sebabagi pelaksana ritual-ritual adat, umunya pernikahan. Akan tetapi bius kerap berkumpul untuk membahas masalah paradaton yang lebih luas. Terkait persengketaan tanah, hukum yang berlaku di huta (desa) dan polemik permasalahan lainnya. Dikarenakan faktor persengketaan dan seragan dari pihak luar masyarakat adat. Muncul kesepakatan baru dalam penyelesaian Sengketa dalam masyarakat adat. Dinamika baru memunculkan lembaga adat sebagai penyambung lidah masyarakat adat itu sendiri. Berbagai kasus sengketa yang bersinggungan dengan hukum positif, biasanya terkait konflik agraria. Munculnya kelembagaan adat dikarenakan sebuah sikap untuk melindungi aset ulayat, tanah adat dan warisan budaya yang dimiliki. Lembaga adat dianggap dapat menjalankan hubungan yang berbeda diantara pihak luar dengan pihak mereka sendiri yang menamakan dirinya dalam satu kesatuan masyarakat adat.

Paradaton, Kejadian dimasa lampau akan turut ambil peran dalam kehidupan di masa kini. Tata nilai yang sudah diperbuat disepakati oleh leluhur, mempengaruhi setiap individu generasi dalam menentukan moralitas perilaku. Merupakan suatu Patik Dohot Uhum (aturan dan hukum). Nilai yang kuat di sosialisasikan, dijalankan, diwariskan dan mempengaruhi kehidupan orang Batak. Paradaton adalah sebuah ikatan yang sakral, sepenanggungan, empati, tanggung jawab, Patik dohot Uhum dalam kehidupan bersama. Mengatur kehidupan untuk saling bahu membahu, tolong-menolong dan saling melengkapi disaparadaton. Kekerabatan mencakup hubungan sedarah, pernikahan dan saling melindungi.

Unsur Dalihan Na Tolu (Hula-hula, Dongan Tubu, Boru). Memberikan sentuhan dalam mengatur setiap pribadi disetiap individu-individu. Saparadaton 
adalah sebuah bentuk hukum yang ada disebuah huta ataupun struktur adat yang lebih besar. Walaupun terkadang lebih dari satu huta masih dalam satu lingkup saparadaton. Peran paradaton dalam huta untuk saling mengukuhkan hubungan yang kuat dalam berbagai hal. Pernikahan, kemalangan, dan pelanggaran, norma dan etika terdapat serasa dan semalu didalam paradaton. Aturan pernikahan sesuai dengan tatanan adat yang berlaku. Paradaton juga sebagai hukum timbal balik. Adat yang diberi kepada suhut begitulah kelak kemudian harus dibayarkan sebagai hutang adat nya. Hutang adat adalah hutang yang wajib dibayarkan, hutang adat akan memberikan pengaruh psikologi yang kuat pada individu yang berhutang adat. Berimbas langsung kepada kehidupan sosial di masyarakat adat.

Perubahan politik tersebut juga berdampak kepada sistem paradaton masyarakat. Awalnya seluruh huta yang ada dalam wilayah marga raja hanya memiliki satu bius dan satu paradaton. Satu paradaton saat ini biasanya adalah penduduk yang wilayahnya berdekatan, bisa satu huta, gabungan beberapa huta, ataupun satu desa. Kesatuan dari beberapa paradaton di satu wilayah disebut dengan horja, di mana ketika mengadakan ritual adat, mereka akan memotong kurban kerbau dan mengundang seluruh raja bius dan penduduk dari satu wilayah tersebut. Suatu ketika diadakan horja di Desa Pusuk Satu, maka seluruh raja-raja huta dari Desa Natam, Desa Janji Hutanapa, Desa Pusuk Satu dan Desa Pusuk Dua harus menghadirinya karena mereka termasuk dalam satu wilayah yang dikenal dengan Negeri Pusuk. Sedangkan untuk Desa Baringin Natam, seharusnya mereka masih termasuk dalam Negeri Pusuk, namun menurut penduduk desa tersebut tidak mengakui bahwa tanah mereka adalah tanah pemberian dari Marga Mahulae sehingga mereka berpisah dari wilayah Negeri Pusuk dan membuat paradaton dan bius yang baru.

Rajanihuta merupakan salah satu galur keturunan marga yang menguasai suatu teritorial yang di garap oleh leluhurnya terlebih dahulu (pamungka huta). Menentukan tapal batas, mendapatkan hak mendirikan dan mendiami di daearah ulayat. Peran Rajanihuta merupakan bagian yang sangat penting didalam persoalan tanah ulayat. Baik itu tanah yang berada dilingkungan huta, sawah, ladang atau diareal hutan.

Dari sisi objek hak, subjek hak atas ulayat bius, partolian, golat, dan huta, berkelompok ataupun perorangan di dalam kelompok marga raja atau marga boru dimaksud Memiliki hak. Pertama, 
Kawasan Hutan: hutan disebut tano rimba dan harangan, hutan muda disebut tombak atau rabi. Jika tanah yang belum pernah dibersihkan itu disebut tano na jadi hea niula atau tano tarulang. Jika sebidang tanah pernah dibersihkan dan sekarang ditinggalkan, itu disebut gasgas atau tano na niulang, atau penyebutan lain yang disetarakan dengan sebutan ini. Kedua, Area Perumahan (Huta): Areal perumahan atau parhutaan terletak pada sebidang tanah berbatasan dengan dua dinding, parik bulu suraton dan parik bulu dun. Keempat sudutnya ditandai dengan pagopago, biasanya batu besar atau pohon besar, atau penyebutan lain yang disetarakan dengan sebutan ini.

Ketiga, Areal Pertanian: Sawah disebut saoa atau hauma. Ladang untuk menanam padi disebut hauma tur. Sebidang tanah yang telah ditinggalkan bera untuk waktu singkat, misalnya dua tahun, yang ditujukan untuk rotasi tanaman, disebut tano dipaombal. Jika tanah untuk tujuan yang sama dibiarkan bera untuk waktu yang lebih lama, maka itu disebut talun. Porlak adalah ladang untuk menanam tumbuhan selain padi, atau penyebutan lain yang disetarakan dengan sebutan ini. Keempat, Area Penggembalaan: Jalangan adalah padang rumput untuk merumput ternak tanpa pengawasan, sementara jampalan atau penyebutan lain yang disetarakan dengan sebutan ini, adalah untuk penggembalaan sapi, kambing atau kuda yang ditambatkan.

Kelima, Area Pencadangan: Area pencadangan disebut berdasarkan tujuan yang berbeda-beda. Hauma harajaon, atau penyebutan lain yang disetarakan dengan sebutan ini, adalah area cadangan untuk mendirikan sawah hasil panen yang digunakan untuk menutupi biaya upacara penawaran di tingkat bius atau bona. Hutan yang dicadangkan untuk kayu bakar disebut tombak ripe-ripe. Tanah yang layak untuk penggembalaan disebut jalangan. Saluran tanah yang diperuntukkan bagi perluasan huta disebut pangeahan atau tamba tamba ni huta. Jika dicadangkan untuk pendatang baru atau yang baru menikah itu disebut punsu tali. Cadangan air disebut mata mual. Keenam, Daerah Suci: Saluran ini diyakini berada di sekitar roh dan jiwa nenek moyang yang mati yang disebut parsombaonan, solobean, parbeguan dan saba parhombanan, atau penyebutan lain yang disetarakan dengan sebutan ini. Kuburan disebut partangisan, parbanadi, atau udean, atau penyebutan lain yang disetarakan dengan sebutan ini. Jika kuburan itu dimiliki oleh orang biasa maka disebut partangisan hatopan, sedangkan kuburan individu disebut partangisan pangumpolan, atau 
penyebutan lain yang disetarakan dengan sebutan ini. Saluran tanah dimana orang melakukan sholat khusus untuk menyembuhkan orang sakit dengan meditasi disebut tano langlang atau parlanglanga, atau penyebutan lain yang disetarakan dengan sebutan ini.

Rajanihuta juga memiliki peran sebagai pengatur adat yang berlaku di wilayah huta. Dalam menjalankan perannya di didamping oleh natua-tua ni huta (sesepuh huta) sebagai memberi saran kepada Rajanihuta. Permasalahan yang paling kerap terjadi biasa tapal batas tanah yang berada diareal perladangan atau didalam tombak ripe-ripe. Ketika keputusan Rajanihuta tidak dapat menyelesaikan masalah. Maka orang akan meminta petunjuk dari arwah leluhur untuk datang melalui mimpi yang dipercayai akan memberikan keputusan pencerahan. Setelah masuknya agama Kristen melalui misionaris. Kegiatan dengan arwah leluhur tidak lagi dilakukan, dilarang oleh agama. Segala persoalan terkait tanah diselesaikan oleh unsur kerabat saripe, jika tidak terselesaikan menghadap ke raja huta dan natua-tua ni huta. Bius juga berperan jikalau permasalahan yang rumit dan terkait paradaton. Melibatkan batas teritorial antar huta. Bius merupakan kumpulan dari beberapa Rajanihuta yang terdiri dari huta-huta diareal yang saling berdekatan biasanya dan masuk dalam rumpun paradaton. Bius mengatur adat, tatanan sosial, dan aspek ritual horja yang ada didalam masyarakat batak. Tanpa terkecuali juga peran bius terlibat dalam sengketa petanahan. Yang biasanya dalam mengatur batas tapal pembuatan huta huta baru dan wilayah tapal tombak ripe ripe. Hingga peralihan atas tanah yang mereka miliki kepada pihak tertentu di luar dari masyarakatnya.

Setiap resesi adat mengalihkan tanah, pelaku mengundang komunitas untuk makan bersama. Disiarkan secara lisan dari mulut ke telinga sebagai pengakuan dan saksi akan peristiwa tersebut. Di setiap resesi itu juga selalu memberikan upeti secara simbolik. Yang berupa ulos, sirih, atau sajian kuliner sakral yang diberikan kepada si pemberi tanah. Sebagai bentuk pelepasan hak akses kepada tanah itu. Setiap perstiwa pengalihan hak itu biasanya diketahui oleh Raja nihuta sebagai pemilik kekuasan atas tanah ulayat yang mereka duduki. Zaman terus bergulir, wilayah teritori adat Batak mendapat daya dorong kuat. Ketika masuknya kolonial Belanda dan pemerintahan Indonesia. Beberapa aspek sistem tradisional yang mereka miliki mendapat daya pengaruh dari corak sistem baru yang tidak dapat dibendung 
lagi. Struktur pemerintahan baru dijaman kolonial Belanda memberikan presser langsung kepada raja nihuta, melemahkan posisi tawar, hingga berkurangnya kekuasaan dari raja nihuta atas hak dan aksesnya pada sumber daya agraria dan tanah. Politik belanda untuk menguasai sumber daya yang ada, menjadikan situasi adat menjadi kacau. Sehingga banyak pertikaian antar huta. Klaim yang semenamena pada akses tanah ulayat mereka. Nilai dan makna tanah bagi masyarakat batak juga berubah kekita era pemerintah Indonesia. Pembangunan dari pemerintah masuk ke wilayah teritori adat. Merubah nilai makna yang bersifat filosifis menjadi nilai ekonomis. Harga tanah yang biasanya tidak dihiraukan, tidak dapat diperjual belikan. Sekarang berubah menjadi bagian investasi yang bernilai profit. Luasan areal tanah dahulunya tidak dapat ditentukan harganya. Hanya diberikan kepada kerabat untuk memperkuat kerajaan dan memperbanyak paripe huta. Setiap peralihan hanya dengan resesi adat, membuatnya tidak bernilai bila dibandingkan dengan nilai harga tanah di zaman sekarang ini. Wilayah areal yang dekat dengan akses transportasi menjadi areal sorotan dan memilki nilai jual tinggi. Setiap perseginya sudah memiliki bandrol sesuai letak strategisnya. Perubahan ini menjadi permasalahan, berlawanan dengan nilai adat yang sudah di anut dari dulunya. Transaksi jual beli sekarang sering terjadi diwilayah tanah ulayat adat.

Gambar 1. Matriks Sistem Hak Masyarakat Hukum Adat Humbang Hasundutan.

\begin{tabular}{|c|c|c|c|}
\hline Sistem Hak & \begin{tabular}{|l} 
Subyek Hak \\
Individu \\
Kelompok adat \\
Kelompok marga \\
Genelogis / Teritorial
\end{tabular} & $\begin{array}{l}\text { Obyek Hak } \\
\text { Tanah dan SDAlainnya } \\
\text { (Huta), perkampungan. } \\
\text { Sawah dan } \\
\text { perladangan. } \\
\text { Hutan adat/Tombak. } \\
\text { Pemakaman } \\
\text { Artefak kebudayaan. } \\
\text { Tempat ibadah } \\
\text { Perbukitan/ Bebatuan. } \\
\text { Sungai. }\end{array}$ & $\begin{array}{l}\text { Jenis Hak/Kewenangan } \\
\text { Pemegang Kuasa Atas Hak } \\
\text { Kelompok Marga pemilik tanah } \\
\text { (Sitombuk Tanoh) (perantau) } \\
\text { Raja nihuta, keturunan pemilik } \\
\text { tanah yang diwariskan secara } \\
\text { genelogis. Berperan sebagai } \\
\text { pengatur tatanan adat, hukum } \\
\text { dan tanah di wilayah huta. } \\
\text { Paripe (penduduk), } \\
\text { Kelompok marga boru, } \\
\text { Kelompok hula-hula, } \\
\text { Pendatang tang } \\
\text { pemilik atas hak guna bangunan } \\
\text { dan tanaman yang tumbuh } \\
\text { dihuta, kepemilikan tanah } \\
\text { dihutan adat } \\
\text { Genelogis/territorial }\end{array}$ \\
\hline $\begin{array}{l}\text { Aspek sosial- } \\
\text { politik } \\
\text { organisasi } \\
\text { komunitas } \\
\text { dan supra } \\
\text { komunitas }\end{array}$ & $\begin{array}{l}\text { Sionom } \\
\text { PBM } \\
\text { Sihas }\end{array}$ & $\begin{array}{l}\text { Ketua } \\
\text { Raja } \\
\text { Bius Raja }\end{array}$ & $\begin{array}{l}\text { Paradaton } \\
\text { Paripe } \\
\text { Perantau/enkulturasi }\end{array}$ \\
\hline
\end{tabular}


Masyarakat adat itu sudah skeptis dengan sistem adat untuk mengatur hak ulayat pada tanah. Dianggap tidak kuat secara legalitas hukum positif Negara Indonesia. Minimnya pengetahuan perundang undangan dan tidak dapat bersinergi dengan undang undang pemerintah. Mereka membuat lembaga yang secara legalitas diakui oleh negara. Lembaga ini kemudian memiliki struktur, yang dimana didalamnya terdiri dari raja bius, pinoppar marga tertentu, perantau dan masyarakat adat didaerah yang tinggal di wilayah teritori adat. Lembaga adat ini sangat terfokus kepada aset agraria yang dimiliki mereka. Dalam satu wawancara dengan lembaga adat mengutarakan, lembaga adat ini diperbuat guna agar dapat melindungi hak aset ulayat mereka dari tindak tanduk transaksi jual beli dengan skala yang besar, khususnya kepada pihak ekseternal atau perusahaan yang bersikap profit dan tidak menghiraukan nasib mereka kedepannya. Lembaga adat ini diperbuat agar kelak anak cucu mereka dapat masih tinggal di daerah adat ini, jikalau tidak maka semua aset mereka terjual dan mereka tidak memilki tanah lagi untuk diwariskan kepada generasi berikutnya. Hal ini mengubah tradisi adat yang hanya melalui resesi adat dan persembahan kepada Rajanihuta. Sekarang semua orang dapat tinggal dihuta jikalau dia dapat membeli tanah dan diizinkan disitu untuk bermukim. Tetapi tidak semua daerah huta, biasanya di daerah yang sudah ramai dan dekat dengan akses pasar. Penyelesaian sengketa tanah juga seiring jaman berubah dari yang sistem tradisional diparaja. Sekarang sudah beralih kepada sistem hukum dan melalui jalur persidangan. Sengketa terkadang tidak melibatkan lagi sistem tradisional yang ada. Keadaan adat semakin melemah secara fungsionalnya. Hal ini yang kemudian mempengaruhi cara berpikir mereka untuk tidak lagi mengacu pada pranata-pranata tradisional, sebenarnya masih hidup dan efektif di beberapa daerah ulayat diwilayah Humbang Hasundutan. Oleh karena itu diharapkan dari hasil penelitian bisa mengembalikan kembali pakem adat yang sudah ada ribuan tahun lalu, untuk membuat satu kebijakan yang saling menguntungkan diantara pihak masyarakat adat, pemerintah maupun investor. Bentuk kearifan masyarakat yang hidup bersama mereka merupakan landasan yang kuat untuk dijadikan suatu pakem untuk mengatur segala aspek hukum terhadap penguasaan sumber daya. Melindungi hingga mendistribusikan hasilnya untuk dijadikan nilai yang profit dalam pembangun negara. Jikalau hal ini berhasil 
tentunya sangat menunjang dalam perkembangan ekonomi di daerah dan pembangunan nasional. Kemakmuran masyarakatnya merupakan tujuan dari suatu negara yang maju makmur dan berdaulat. Sehingga hal ini harus dapat diperjelas dengan perundang undagan yang jelas di masyarakat adat dan pemerintah lokal maupun pemerintah nasional.

\section{SIMPULAN}

Bagi orang Batak, tanah tidak hanya sekedar aset. Tanah memiliki fungsi, makna yang sangat luas dan dalam. Secara simbolik tanah merupakan penunjukan identitas. Merupakan tujuan hidup filosofis yang diwarisakan leluhur. Memberikan derajat yang tinggi seorang Batak. Batas teritorial kekuasaan atas tanah (SDA) yang luas. Lebih jauh lagi hubungan orang Batak dengan tanah melibatkan segala unsur sosial didalam komunitas adat di wilayah Humbang Hasundutan. Baik itu dari segi kekerabatan, politik, hukum, lingkungan, ekonomi, terotorial kekuasaan dan religi. Di masyarakat adat Humbang, sistem adat merupakan instrumen yang mengatur kepemilikan dan akses terhadap tanah. Mekanisme adat, untuk dapat menguasai, memiliki tanah diwilayah komunitas. Masih menggunakan sistem tradisional, yang hingga sekarang masih ditemukan.
Mekanisme itu merupakan pewarisan ulayat secara galur keturunan. Diwariskan kepada kerabat terdekat, merupakan anak, adik, abang dan boru dari saripe galur marga pemilik tanah (pamungka huta). Kemudian mekanisme melalui pernikahan. yang merupakan kontrak dan transaksi yang sah secara adat. Mendapatkan pengakuan dari komunitas batak. Dalam substansi pelepasan hak dari pihak pemilik tanah dengan penerima, semua itu harus melakui tahapan resesi adat. Resesi adat ini disebut pago-pago, ulos na so buruk dan berbagai macam ungkapan lainnya tergantung posisi kepada siapa tanah itu diberikan dan dimana lokasi itu berada.

\section{UCAPAN TERIMAKASIH}

Ucapan terima kasih yang sebesarbesarnya kepada Bapak/Ibu yang merupakan orang-orang yang sangat berperan besar dalam penelitian ini. Kepada Yayasan Doktor Sjahrir dan Dr. Kartini Sjahrir yang sudah mendukung secara penuh kegiatan penelitian ini. Mas $\mathrm{R}$ Yando Zakaria yang merupakan orang paling berpengaruh dalam penelitian ini dan metode metode penelitian ditingkat lapangan. Dr. Fikarwin Zuska yang banyak memberikan masukan dalam mekanisme dan teknik penulisan. Freida Amran dengan naskah dan arsip lama zaman kolonial. Rio Belvage dan Yohana 
Marpaung yang merupakan teman sejawat dalam mengumpulkan setiap data untuk melengkapi naskah penelitan ini. Informan yang sudah menyediakan waktunya untuk diwawancarai baik dari masyarakat, orang tua di huta dan dinas yang terkait yang membantu kegiatan penelitian ini. Oleh karena itu tiada kalimat yang lebih baik selain ucapan terima kasih kepada beliau sekalian. Semoga Allah SWT selalu melindungi kalian dimanapun berada dan diberikan umur yang panjang agar tetap berbakti kepada bangsa dan negara.

\section{DAFTAR PUSTAKA}

Adhuri, D.S. (2013). Selling the Sea, Fishing for Power. A Study of conflict over marine tenure in Kei Islands, Eastern Indonesia. Asia-Pacific environment monograph No.8. Canbera: ANU E Press.

Bagan statistik terkait dengan jumlah penduduk dari tahun 2005-2013, bersumber pada https://databoks.katadata.co.id/datapublish 2016/05/12/jumlah-penduduk-dikabupaten-humbang-hasundutan-sumaterautara-2004-2013,

Pasya, G. \& Sirait, M.T. (2011). Analisa Gaya Bersengketa Panduan Ringkas untuk Membantu Memilih Bentuk Penyelesaian Sengketa Pengelolaan Sumberdaya Alam. Bogor, Indonesia The Samdhana Institute.

Prosentase luasan hutan, gambaran demografi dan kepadatan penduduk, didapat dari
https://id.wikipedia.org/wiki/Kabupaten $\mathrm{H}$ umbang Hasundutan,

Sibarani, R. (2013). Pendekatan Antropolinguistik Terhadap Kajian Tradisi Lisan. Medan: Jurnal USU.1-16.

Simanjutak, S. (2014). “Merampas Haminjon, Merampas Tanah: Pandumaan-Sipituhuta Melawan Toba Pulp Lestari”. Working Paper Sajogyo Institute No.26, 2014.

Simarmata, C.I.D, (2017). "Keharmonisan Adat Batak dalam Lingkaran Dalihan Na Tolu" dari laman

https://www.kompasiana.com/cha2han/ke harmonisan-adat-batak-dalam-lingkarandalihannatolu 5529d5e56ea8345844552 cfe,

Simbolon, I.J. (1998). "Peasant Women and Access to Land: Customary Law, State Law and Gender-Based Ideology, The Case of the Toba-Batak (North Sumatra). Wageningen University.

Situmorang, S. (2009). "Toba Na Sae: Sejarah Lembaga Sosial Politik Abad XIII-XX". Jakarta: Komunitas Bambu.

Spradley, P.J. (1997). Metode Etnografi. Yogyakarta: Tiara Wacana

Steward, J.H. (1972). "Ecology: Cultural Ecology." International Encyclopedia of the Social Science.

Undang Undang RI No. 32 tahun 2009.Perlindungan dan Pengelolaan Lingkungan Hidup. Kementerian Negara Lingkungan Hidup, Jakarta.

Vansina, J. (2014). “Tradisi Lisan sebagai Sejarah”. Yogyakarta: Ombak.

Vergouwen, J.C. (2004). "Masyarakat dan Hukum Adat Batak Toba". Yogyakarta: LKiS.

Wunter, H, \& Bergesen, K. (1984). Cultural Analysis, The Work of peter L.Berger, M Doughlas, Michael Foucalt, and Jurgen Habermas.

Zakaria, R.Y, Emil O. Kleden,Y.L. \& Franky, (2011). MIFEE, Tak Terjangkau Angan Malind. Jakarta: Yayasan PUSAKA, The Climate and Land Use Alliance (CLUA), dan Rights and Recources Initiative (RRI). National Geographic Edisi Indonesia, Juni 2009. 